\title{
KARL VON DEN STEINEN E A EXPLORAÇÃO CIENTÍFICA DO BRASIL *
}

\author{
Egon Schaden \\ Professor da Universidade de São Paulo
}

\section{Nota biográfica}

Em 7 de março de 1955 transcorreu o centésimo aniversário do nascimento de Karl von den Steinen, cientista ativo e competente que, realizando duas expedições às nascentes do Xingu, contribuiu de maneira notável para o conhecimento das nossas culturas indígenas e, de modo geral, para a exploração científica do Brasil.

Natural de Mühlheim sôbre o Ruhr, Karl von den Steinen concluiu - curso secundário aos 16 anos de idade, passando a estudar medicina em Zurique, Bonn e Estrasburgo, e especializando-se depois como psiquiatra em Berlim e Viena. Interessado na investigação de problemas ligados às enfermidades mentais e ao seu tratamento nos diferentes países, empreendeu aos 24 anos uma viagem em redor do mundo (1879-1881), por ocasião la qual se encontrou na Polinésia com Adolf Bastian, o fundador do museu etnológico de Berlim. O fato teve importância decisiva para o jovem cientista, cuja carreira, confessava-o êle próprio, teria tomado rumo bem diverso, não houvesse êle deparado no registro de hóspedes do hotel de Honolulu com a indicação "Dr. Bastian - Berlim". Bastian cativou-o logo através do poder sugestivo de sua personalidade, entusiasmando-o pela etnologia ${ }^{1}$. Imediatamente von den Steinen pôs mãos à obra, colhendo com algumas tribos polinésicas as suas primeiras experiências, que mais tarde, daí a vários decênios, quando realizou o estudo exaustivo da arte dos marquesanos, sôbre a qual escreveu uma obra prima em três volumes, se the haveriam de revelar bastante úteis. A viagem seguinte, de 1882 a 1883, realizou-a à Geórgia meridional na qualidade de membro রa expedição alemã à região polar, incumbido principalmente de fazer observações no campo das ciências naturais. Ao regressar, empreendeu em 1884, partindo de Buenos Aires, a sua primeira expedição etnológica ao território do alto Xingu, no Brasil Central. Nos anos de 1887 a 1888 tornou a percorrer a região, com o intuito de visitar as tribos indígenas do Kulisehu, tributário oriental do Xingu. Depois de voltar à pátria, dedicou-se à elaboração do material colhido, foi nomeado professor da Universidade de Marburgo e, a seguir, de Berlim, realizou

*) O presente trabalho, escrito em língua alemã para o "Staden-Jahrbuch" (edição do Instituto Hans Staden, São Paulo), que o publica $\epsilon \mathrm{m}$ seu $4 .^{\circ}$ volume (correspondente a 1956), foì apresentado, em português, à 2a. Reunião Brasileira de Antropologia, realizada em Salvador no mês de julho de 1955 . 
uma expeđicão cientifica às Thas Marquesas e organizou a secção sulamericana do museu etnológico de Berlim, onde mais tarde exerceu as funcões de diretor. Frcleceu no dia 4 de novembro de 1929 em Cronberg no Taunus.

\section{Posição científica}

No tocante às suas preocupações teóricas, Karl von den Steinen pertencia a uma corrente etnológica ordinàriamente caracterizada pelo rótulo de evolucionismo. Adolf Bastian, o principal representante dessa teoria na Alemanha, esforçava-se naquele tempo, através de inúmeros livros e artigos, por fundamentar uma ciência humana que, p€lo recurso aos conhecimentos etnológicos, levasse finalmente a uma nova psicologia, mais bem alicerçada. Tratava-se de investigar a psique através de sua manifestação na pluralidade das configurações culturais, que, porém, sempre e em tôda parte teria por base a unidade fundamental do gênero humano. Filha do século dezenove, essa teoria, orientando-se pela noção do progresso, levava os cientistas, no estudo dos povos primitivos, a descobrir o que nestes houvesse de primitivo ou pouco diferenciado, com o objetivo de determinarem a linha geral da evolução das culturas. Deve-se todavia notar que Bastian e sua escola não tomaram sem mais nem menos da idéia de evolução tal qual ela se difundia ràpidamente pelos escritos de Darwin, transpondo-a para o domínio da pesquisa etnopsicológica e etnológica. O próprio Bastian, por exemplo, era adversário decidido do evolucionismo biológico. E, além do mais, os referidos etnólogos, embora interessados primordialmente na descoberta de leis interiores que reg€ss€m os processos de mudança cultural, não deixaram, contudo, de investigar também as relações histórico-culturais, na medida em que lhes parecessem significativas e passíveis de análise no tempo e no espaço, quer se tratasse das migrações desta ou daquela tribo, quer da transmissão de determinados elementos culturais. Era natural que tais fatos ocupassem o segundo plano na ordem das cogitações, uma vez que se tinha em mente a constituição de uma etnologia como disciplina psicológica, e não histórica. E isto por sua vez decorria do fato de até os fins do século passado faltarem de todo os estudos metodológicos que pudessem servir de base a uma etnologia como história cultural dos povos primitivos, ou seja, das tribos "sem história".

A posição científica de Karl von den Steinen era, sem dúvida, €volucionista, porquanto êle se preocupava, antes de mais nada, em reconhecer no aborígene brasileiro o homem da idade da pedra, investigando-lhe as formas de vida ccm a finalidade de, como êle próprio dizia, obter uma visão mais profunda da pré-história do espírito. Com efeito, interessavamno especialmente os problemas relativos à origem dos mais variados elementos culturais. Por outro lado, não deixou de dar atenção às relações históricas, sempre que a sua análise the parecesse elucidativa. De mais a mais, os esforços no sentido de se remontar às origens dos elementos 
culturais se prendem necessàriamente a tôda teoria etnológica que focalize a dimensão temporal das culturas, quer seja ela uma teoria evolucionista, quer histórico-cultural. Assim, por exemplo, o Pe. Wilhelm Schmidt, notável propugnador e representante da etnologia histórica, escreveu uma obra em doze volumes sôbre a "origem da idéia de Deus", embora se conservasse até o fim da vida inimigo ferrenho de qualquer forma de especulação evolucionista.

\section{As viagens}

A contribuição de Karl von den Steinen para o conhecimento científico do Brasil começa no campo da geografia. Antes dêle, ninguém conseguira - nem pelo lado de Cuiabá, nem pelo norte - determinar as nascentes do Xingu. Em 1843 tentara-o o Príncipe Adalberto da Prússia, subindo o rio até a aldeia indígena de Piranhaquara, situada a $4^{\circ}$ de latitude sul; tivera de voltar, porém, pela impossibilidade de vencer as cachoeiras. Karl von den Steinen, partindo em 1884 da capital matogrossense em companhia de seu primo Wilhelm von den Steinen e do físico e astrônomo Otto Clauss, rumou primeiro para as aldeias dos Bakairí mansos do Rio Novo e do Paranatinga, na região do alto Tapajós. Prosseguindo em direção nordaste, os expedicionários atingiram as nascenter do Batovi (denominado Tamitotoala pelos índios), desceram o rio até a sua embocadura no Xingu, continuando por êste até o Amazonas. De Cuiabá até Belém a jornada durou mais de cinco meses. Estavam descobertos os confluentes do Xingu, e Clauss, além de fazer o levantamento cartcgráfico até Piranhaquara, realizara inúmeras Jbservações meteorológicas ${ }^{2}$.

E' fácil imaginar os perigos de uma expedição dessa natureza. O govêrno imperial, aliás, recebeu com desconfiança a idéia do audacioso plano. Lcgo que o Ministério dos Estrangeiros tomou conhecimento do rojeto da expedição, o diretor do Museu Nacional do Rio de Janeiro, Ladislau Neto, foi incumbido de elaborar um parecer. Na informaçăo que redigiu lê-se que os três alemães de maneira alguma poderıan percorrer as nascentes do Xingu, a menos que se lhes proporcionassen recursos especiais; que seria indispensável fazê-los acompanhar de uma bem selecionada fórça militar e de alguns intérpretes conhecedores dus iđiomas indígenas da região; que, ademais, seria recomendável enviarIhes ao encontro, Tapirapé acima, um grupo de vaqueanos e intérpretes; que, entretanto, o melhor de tudo seria conseguir que os três estrangeiros desistissem da difícil tarefa, que afinal incumbiria ao govêrno do Império e da qual se tornara vítima Crévaux; que, aliás, o govêrno francês, após a morte de Crévaux, havia preparado nova expedição, com o oijetivo de explorar o Xingu da embocadura em direção às nascentes ${ }^{3}$. Como quer, porém, que fôsse, o governador de Mato Grosso, Barão de Batovi, recebeu recomendação especial de apoiar o intento dos três alemães, que, por seu turno, traziam de Buenos Aires uma carta ao repre 
sentante brasileiro com a informacão de que o imperial Ministro da Guer. ra havia determinado se fizesse acompanhar a expedição de uma escôlta militar. Partiram, assim, de Cuiabá com 25 soldados sob o comando de dois capitã€s; un dêstes, todavia, depois de poucos dias teve de set mandado de volta por causa da escassez de mantimentos e de outras dificuldades.

Concluída com êxito a expedição, os viajantes foram alvo, no Rio de Janeiro, das mais ineqüívocas manifestações de reconhecimentว pelos serviços prestados. O diretor do museu, que antes se pronunciara contra o audacioso projeto, comunica agora ao govêrno imperial a exploração do Xingu, observando tratar-se de um dos acontecimentos "mais importantes para as ciências e geografia desta parte da América", e lembrando a conveniência de se remunerarem condignamente os viajantes com uma distinção honorífica " A "Sociedade Brasileira de Geografia" fêz questão de incluir os expedicionários em seu quadro social (9-12-1884), recebendo-os em sessão solene na presença do imperador (30-12-1884). Honra seme!hante thes foi tributada pelo "Instituto Histórico e Geográfico Brasileiro" 5 .

Conquanto na segunda viagem ao Xingu (1887-1888), destinada especialmente à solução de determinados problemas etnológicos, o interêsse geográfico não passasse para o primeiro plano, não se pode dizer que não tenha alcançado importância também neste sentido. Karl von den Steinen seguiu novamente em companhia de seu primo Wilhelm von den Steinen, que, na qualidade de exímio desenhista, já prestara bons serviços na viagem anterior. Integravam a expedição o etnólogo Paul Ehrenreich e o astrônomo Peter Vogel, além do Tenente Luís Perrot, pôsto à disposição dos cientistas pelo govêrno imperial.

O estímulo para o novo empreendimento dera-o um mapa das nascentes do Xingu com as respectivas populações aborígenes riscado na areia em 1884 por um chefe da tribo Suyá. Viajava-se agora em procura das aldeias índias que deviam existir nas margens de um confluente mais oriental, o Kulisehu, rio ainda inteiramente desconhecido também do ponto de vista geográfico. Partindo de Cuiabá em fins de julho de 1887, a expedição atravessou o Batovi um pouco acima do ponto em que três anos antes se haviam tomado as cancas, avançou até o Kulisehu, sહguindo-o - primeiro pelas margens, depois sôbre a água - até a sua confluência com o Xingu. Destarte foì possivel fazer também o levantamento cartográfico do Kulisehu. Uma série de contratempos, como doenças e falta de mantimentos, cêdo forçaram os viajantes a regressar a Cuiabá, orde chegaram, por um caminho diferente, na véspera do Ano Bom. Antes de seguir para o Rio de Janeiro, fizeram ainda uma visita aos Borôro do São Lourenço, a sueste da capital mato-grossense ${ }^{6}$.

O etnólogo

Para ap:eciar em seus devidos têrmos o alcance da contribuição de Karl von den Steinen para a exploração etnológica dos indígenas brasi- 
leiros, bem como a influência que exerceu no desenvolvimento da etnologia na Alemanha, seria necessária uma extensa dissertação. Contentemo-nos aqui com algumas observações. Numa pequena conferência, realizad̉a por ocasião do $31 .^{\circ}$ Congresso Internacional de Americanistas (São Paulo, agôsto de 1954), já procuramos pôr em relêvo certo número de aspectos significativos ${ }^{\top}$. De modo geral, convém acentuar que o mérito de Karl von den Steinen decorre menos dos resultados imediatos de suas expedições científicas do que da influência decisiva que the coube exercer, em parte consciente e diretamente, $€ \mathrm{~m}$ parte indiretamente, sôbre o espírito de cutros sábios que vieram deđicar-se ao estudo das populações tribais brasileiras. Em belo necrológio, que the dedicou o sueco Erland Nordenskiöld, lê-se a justa observação de que não raro algumas poucas linhas da autoria dêsse homem genial foram suficientes para inspirar tratados inteiros a outros ${ }^{8}$.

Difìcilmente haverá um especialista em etnologia brasileira que deixe de reconhecer que os resultados das duas referidas expedições ao Xingu no último quartel do século passado abriram uma nova éra no estudo de nossas culturas aborígenes. A obra básica para o conhecimento dos indígenas brasileiros fôra até então o compêndio "Beiträge zur Ethnographie und Sprachenkunde Amerikas zumal Brasiliens", da autoria de K. F. Ph. von Martius. Esse trabalho, publicado em 1867, continha uma visão panorâmica do conjunto das tribos brasileiras até então conhecidas, diligentemente elaborada mediante recurso a tôdas as fontes de informação acessíveis, mas que não obstante não podia deixar de ser excessivamente esquemática e imperfeita. E se cabe a afirmação de que as viagens de von den Steinen se encontram no limiar de uma nova fase, é sobretudo porque depois delas os especialistas, longe de se contentarem com a compilação de notícias mais ou menos fortuitas, passam à investigação sistemática de determinados conjuntos de problemas ${ }^{9}$.

Lembra o Barão de Nordenskiöld, no mencionado necrológio, que foi uma felicidade não ter sido feita a primeira exploração do Xingu por um viajante que não tivesse outra ambição senão a de preencher alguns claros do mapa com nomes de rios e serras; e, mais ainda, terem-no levado as suas expeđições a uma área habitada por tribos portadoras de cuituras ainda pouco influenciadas pela civilização.

Pois, como acima dissemos, a etnologia da época procurava, antes de mais nada. remontar até o berço da humanidade, a fim de melhor compreender, através da evolução dos sistemas de vida, a própria natureza humana. Problemas dessa ordem, no entanto, podiam ser discutidos sòmente com referência a tribos que não tivessem perdido as suas características originais pelo contacto com o mundo ocidental. As observações que pôde fazer entre os Bakairí, os Nahukuá, os Mehinakú ,os Kustenáu, os Auetö, os Yaulapití, os Kamayurá e outros índios proporcionaram a Karl von den Steinen numerosos pontos de apôio para a tentativa de ex- 
plicar a origem dos mais diversos elementos da cultura material a nãomaterial. Diante da posição teórica em que se instalara, compreende-se que na formulação das hipóteses muitas vêzes deixasse de ấender a umas tantas diferenças entre uma cultura e outra, que a nós hodiernos talvez pareçam essenciais, mas que para êle eram pouco significativas, uma vez que as tribos pertenciam tôdas mais ou menos ao mesmo "estágio" cultural. Entre os problemas que mais o interessavam estava o da origem dos adornos e da indumentária, o da invenção da cerâmica, da descoberta do molinilho de fazer fogo, das origens do desenho ornamental e da representação plástica, da magia, das representações com máscaras e das danças - problemas que investigava no intuito de melhor compreender a mentalidade do homem primitivo. E é de justiça assinalar, por exemplo, que não será fácil encontrar, na literatura etnológica anterior às páginas de von den Steinen sôbre o mito dos heróis e outros textos Bakairí, interpretações de alguma tradição mítica que ponham a descoberto com igual perspicácia a concepção do mundo que nela se espelhe. As incursões pelo terreno da mentalidade e da estrutura do pensamento dos índios induziram-no a examinar a sua arte de contar e a formular uma teoria sôbre a origem do número 2 , conceitó que teria nascido da divisão do todo em suas metades. Certo, muitas dessas idéias estão hoje antiqüadas; mas, em lugar de ridicularizá-las, talvez convenha lembrar que, em oposição a hipóteses anteriores, essas tentativas de compreensão marcavam notável passo à frente no sentido de tôdas elas, embora altamente especulativas, se basŁarem na observação direta do aborígene.

As dificuldades que teve de vencer no levantamento do idioma $\mathrm{Ba}-$ kairí - e que podem ser avaliadas sòmente por quem já tenha enfrentado tarefa sımelhante - levaram a atenção do sábio para o problema das relações entre a língua e a estrutura do espírito, considerado sobremodo significativo também na etnologia contemporânea. A fím de mostrar a maneira pela qual abordava tais questões, citamos um trecho de sua obra principal: "A pobreza de seu idioma consiste essencialmente na faita de conceitos genéricos, como se dá com todos os povos primitivos. Têm uma palavra para "ave", que provàvelmente significa "alado", mas cs Karaíb do norte têm um outro radical, toro - ou tono - , que ainda é empregado pelos Bakairí para designar determinadas aves, muito comuns, uma espécie de papagaios ou de galináceos silvestres. Cada papagaio tem seu nome especial; o têrmo mais geral "papagaio" falta inteiramente, como também não possuem palavra para dizer "palmeira". Conhecem, porém, muito bem as características de cada espécie de papagaios e de palmeiras, e prendem-se assim a esta infinidade de conhecimentos particulares, de modo que não se incomodam com os caracteres comuns, destituídos de interêsse. Vê-se, pois, que a sua pobreza é apenas uma pobreza em unidades mais elevadas; sufoca-os a quantidade da matéria e são incapazes de dominá-la de forma econômica. Só têm, até ago- 
ra, um intercâmbio com moeda divisionária, mas, quanto ao número de unidades que possuem, devem ser antes considerados como riquíssinos do que como pobres. Na construção de seus pensamentos, reunem os conceitos como que para formar um muro incomensuràvelmente longo de pedras tôdas iguais, e quase não têm ainda idéia do que seja umá estrutura arquitetônica" 10 .

Um dos problemas a que von den Steinen dedicou particular interêsse era o da pátria primitiva dos Karaíb. Compreendendo que não o poderia resolver exclusivamente sòbre a base de uma etnologia de orientação psicológica, não teve dúvidas em estender as suas pesquisas ao campo das relações histórico-culturais e lingüísticas. Ao contrário da opinião tradicional, que fôra defendida, por exemplo, por Alexander von Humboldt, e segundo a qual as tribos Karaíb, vindas do norte, se teriam espalhado por vastas áreas do continente sul-americano, a tese de von den Steinen aponta os Karaíb do Brasil Central, especialmente os Bakairí e Nahukuá por êle visitados, como os mais primitivos, quer do ponto de vista lingüístico, quer do cultural, e o território em que vivem, as nascentes do Tapajós e do Xingu, como a pátria de origem de tôda a fan ília lingüística. Partindo dessa região, os Karaíb no decorrer de muitos séculos se teriam deslocado, em levas sucessivas, em direção ao norte do continente, atingindo afinal as Pequenas Antilhas. Formada pelo explorador logo em sua primeira viagem, e por êle apoiada depois com argumentos de ordem lingüística, etnobotânica e de outra natureza, essa opinião tem sido submetida à apreciação crítica por outros especialistas, mas até hoje nenhum dêles a refutou de maneira cabal. No afã de determinar o foco de irradiação e as rotas migratórias dos Karaíb, o etnólogo se aplicou à análise da distribuição e das relações culturais das tribos indígenas na zona tropical sul-americana, conseguindo elucidar vários aspectos no sentido de garantir maior segurança no levantamento de problemas significativos a serem enfrentados de maneira sistemática por outros pesquisadores.

Seria injusto, pois, não insistir no extraordinário impulso que as obras e a influência pessoal de Karl von den Steinen imprimiram, principalmente na Alemanha, ao estudo de nossas culturas indígenas. A Paul Ehrenreich, seu companheiro na segunda expedição ao Xingu, sugeriu. que a seguir viajasse pelo Araguaia e pelo Purus, com o fito principal de verificar a existência de tribos intermediárias entre os Karaíb do Brasil Central e os das Guianas, que, por conseguinte, servisse de argumento em favor da hipótese há pouco referida. Depois, nos anos de 1895 e 1898, o alto Xingu foi visitado por Herrmann Meyer (o fundador de Neu-Württemberg, hoje Panambi, no Rio Grande do Sul), e em 1900 seguiu-se a quinta expedição alemã a êsse território, dessa vez a cargo de Max Schmidt. Theodor Koch-Grünberg, discípulo de von den Steinen, que acompanhara a Herrmann Meyer em sua primeira viagem, veio dedicar- 
se ao estudo das populações aborígenes do noroeste brasileiro e de outras áreas setentrionais da América do Sul, onde a morte o colheu em 1924. - Bastam êstes nomes para dar uma idéia dos incentivos que a etnulogia de nossos índios recebeu do primeiro explorador das nascentes do Xingu.

A esta altura vale a pena salientar mais um aspecto. Graças ao seu estilo vivo, cheio de humor e isento de artificialidade, à sua preocupação de não se perder desnecessàriamente no reino das considerações abstratas e à amizade pelo índio, que transparece constantemente na descrição da viagem e no tratamento das questões científicas, Karl von den Steinen conseguiu como talvez nenhum outro etnólogo dos princípios dêste século encontrar também grande repercussão e numerosos leitores entusiasmados fora do âmbito dos especialistas. A primeira edição de seu livro principal, "Unter den Naturvölkern Zentral-Brasiliens", vendeu-se em pouco tempo, o que levou a casa editôra a cogitar de uma edição popular, mais barata. Com satisfação, o autor aceitou a idéia, dizendo-se feliz por ter a oportunidade de apresentar a um público menos restrito a imagem viva e genuína do índio, tal qual êle a obtivera por sua própria experiência, imagem que se contrapunha à construção fantástica, bem comum na época, de um "selvagem livremente inventado por via de abstração a partir do homem civilizado, selvagem que, sacudido de arrepios no seio da mata ou na queimada das pradarias, envia as suas orações para o alto; que, observando a ave a construir o ninho, a aranha, a tempestade a fustigar os ramos, inventa as técnicas do trançado, da fiação, da obtenção do fogo; que se veste por sentir vergonha da nudez $(\ldots)^{\prime 11}$. Significativo é, porém, que a edição popular da obra não se distingue da anterior por uma redação simplificada, mas, em essência, pelo corte de alguns capítulos ou trechos. Já na primeira edição, o autor, como êle mesmo o exprime, não fugira ao prazer de escrever de modo a ser compreendido por qualquer pessoa.

O estudo científico dos idiomas indígenas

No setor da lingüística americana, Karl von den Steinen realizou principalmente três tarefas de relêvo: em primeiro lugar, elaborou minucioso estudo monográfico do idioma Bakairí; em segundo, apresentou nová classificação das famílias lingüísticas ameríndias do Brasil, e, finalmente, publicou uma edição comentada de um dicionário Sipíbo baseado no manuscrito de um missionário franciscano anônimo.

"Die Bakaïrí-Sprache"12, hoje obra clássica da lingüística sul-americana, não é apenas a gramática de um idioma indígena, mas uma inteligente análise comparativa, empreendida com o intuito de pôr a descoberto as características do idioma fundamental Karaíb. Tomando por base o material sôbre a língua Bakairí colhido na segunda expedição ao Xingu - um vocabulário, numerosas frases e alguns textos míticus e utilizando todos os vocabulários e gramáticas de outros idiomas $\mathbf{K a}$ - 
raíb da América Meridional e Central que pôde encontrar, o autor se entregou à tarefa de apontar os traços essenciais da língua Karaíb original, explicando, com referência a determinadas leis fonéticas, as transformações que marcam a evolução dos diferentes idiomas do grupo. A segurança do juízo, como a perspicácia com que investiga até as mais insignificantes peculiaridades do idioma Bakairí, despertam verdedeira admiração no leitor, principalmente quando se lembra de que o autor, não sendo lingüista de formação, se muniu supletivamente dos conhecimentos nesse setor, em que haveria de destacar-se de forma tão notável 1:.

A primeira classificação geral das línguas indígenas do Brasil foi proposta por von Martius. Um dos méritos principais de seu trabalho consistia em destacar os idiomas Jê como família especial, sem que, no entanto, o quadro dêsses idiomas resistisse, em seus pormenores, à crítica de épocas posteriores. Outro grande grupo do sistema de von Martius era o das línguas Guck, que incluía tôdas aquelas que designam o tio com o têrmo "guck" ou "kokko". Von den Steinen conseguiu demonstrar, já após a primeira viagem, a inaplicabilidade dêsse critério, e a segunda expedição the forneceu novo material para a revisão da classificação dos idiomas aborígenes do Brasil. Graças a uma feliz intuição, dirigira-se exatamente ao centro geográfico do Brasil, o alto Xingu, onde se haviam instalado, em área bastante restrita, tribos representantes das maiores famílias lingüísticas ${ }^{14}$.

O "Diccionario Sipibo" contém o registo vocabular de uma língua Páno da região do Ucaiale. Embora os índios em aprêço não se encontrem em território brasileiro, o livro é de interêsse para o conhecimento de nossa linguística, porquanto os comentários do cientista se referem também a tribos Páno que vivem ou viviam aquém da fronteira. Quanto ao manuscrito, von den Steinen o adquirira a Richard Peyer, velho viajante da Amazônia. Procedendo, na elaboração, com o zêlo científico já demonstrado nos trabalhos anteriores, enriqueceu a bibliografia americanista com uma obra de real utilidade, aliás uma das primeiras relativas a um idioma do grupo Páno ${ }^{15}$.

\section{A questão dos sambaquis}

Dentre as disciplinas que têm por objeto o Brasil indígena, a arqueologia tem sido uma das menos cultivadas, razão pela qual não estamos nem hoje em dia em condições de esboçar um quadro satisfatório de nossa pré-história. No conjunto das contribuições de Karl von den Steinen à exploração científica do Brasil, que dizem respeito sobretudo à etnologia e à lingüística, a arqueologia ocupa por sua vez o terceiro lugar. Não obstante, merece menção um relatório quase desconhecido sôbre o problema dos sambaquis ${ }^{16}$. Quando, em princípios de 1887, chegaram ao Rio de Janeiro os componentes da segunda expedição ao Xingu, não podendo seguir para Cuiabá, por causa da epidemia de cólera 
que grassava em Mato Grosso, Karl von den Steinen resolveu aproveitar a involuntária demora para pesquisar os sambaquis de Santa Catarina. Visitaram-se ao todo 14 concheiros, especialmente em São Francisco, no norte, e na Laguna, no sul da província, reunindo-se uma boa coleção (amcstras de estratos, crânios e outros restos de esqueletos, utensílios de pecra etc.) para o museu de Berlim, e examinando-se tôdas as questöes fundamentais ligadas aos concheiros e a sua origem. Von den Steiner, experimentado naturalista, observou uma série de fatos que a outros haviam escapado. Pôde, assim, reformular o problema dos sambaquis num trabalho conciso e, em sua maior parte, constituído de referências pouco explícitas, mas que, entretanto, fornecia novos pontos de vista para discussões ulteriores. Mediante análise dos perfis dos concheircs, reexamirou a questão da estratificação de muitos dêles, relacionado a diferente estrutura dos sambaquis com as peculiaridades geográficas dos arredores. Comparando os concheiros de São Francisco com os da Laguna, chegou à conclusão de que as camadas de areia encontradas nestes últimos proviriam da areia movediça das dunas existentes naquela parte do litoral catarinense. Ponderando sagazmente cs argumentos, tentou explicar a origem dos sambaquis, chegando à opinião, ainda hoje defersável, de que, ao menos numa parte dos concheiros, preponderantemente as camadas inferiores remontariam à forn:ação natural da costa, ao passo que a idéia de se tratar de sítios de moradia e restos de cozinha (os chamados Kjökkenmöddinger) se aplicaria melhor às camadas supericres, nas quais se descobre maior número de esqueletos humanos e grande quantidade de objetos de pedra. Abordou igualmente o problema da unidade ou pluralidade racial e cultural dos homens que outrora habitaram os sambaquis, dando, em resumo, ao leitor, ainda hoje em dia, a impressão de que o relatório, embora conśtituído de apenas poucas páginas, continua sendo uma das contribuições mais sensatas que se têm escrito sôbre o assunto. Por isso mesmo é pena que não se oferecesse ao cientista ensejo de aprofundar mais o estudo dêsse tema, que precisamente em nossa época vem despertando a curiosidade de muitos espíritos.

\section{$O$ alto Xingu em nossos dias}

Faz setenta ancs que as primeiras expedições avançaram para o centro gecgráfico do Brasil. De então para cá, muita coisa mudoù naquelas florestas. As tribos da região, até os fins do século dezenove pràticcmente isentas das influências da civilização ocidental, recebem hoje a visita regular de aviões modernos e já conhecem bom número dos bons e dos maus aspectos de nossa forma de vida. E' com bastante receio que os amigus do índio registram o desbravamento demasiado rápido dêsse território de promissor futuro econômico; não tardará, por certo, 
a acarretar o extermínio total dos aborígenes que aí vivem a cujo número já agora começa a diminuir de forma sensível.

Junto ao Govêrno Federal se vem desenvolvendo, há anos, urn movimento no sentido de se transformar em "Parque Nacional do Xingu" a uma parte considerável da bacia dêsse rio, isolando-a do mundo restante, e garantináo, dessa maneira, ao aborígene maior seguranca e a posse cias terras que desde sempre the pertenceram. A tais pretensões, porém, se opõem ponderáveis interêsses particulares, o que deu origem a uma luta ainda não decidida.

A exploração científica da área fêz bons progressos. As conđições geográficas, bem como a fauna e a flora estão ern parte estudadas de modo sistemático, o que se tornou possível graças à cooperação đe várias instituições, entre as quais o Museu Nacional, do Rio de Janeiro. Por seu turno, as culturas das tribos xinguanas têm continuado a merecer a atenção dos etnólogos; assim mesmo, numerosos problemas não foram ainda investigados do ponto de vista das teorias modernas. Em conseqüência da mudança das condições de vida, as culturas se transformam em ritmo crescente. Não há, pois, tempo a perder. Oxalá Karl von den Steinen encontre, antes que seja tarde, um número suficiente de sucessores ativos e capazes.

\section{NOTAS:}

(1) Karl von den Steinen, Gedächtnisrede auf Adolf Bastian. Zeitschrift für Ethnologie, vol. XXXVII, págs. 236-249. Berlim, 1905.

(2) Os resultados principais dessa viagem foram expostos na obra de Karl von den Steinen, Durch Zentral-Brasilien. Expedition zur Erforschung des Schingú im Jahre 1884. F. A. Brockhaus. Leipzig, 1886.

(3) "Ofício informando o Aviso do Ministério dos Estrangeiros relativo ao projeto de três exploradores alemães que desejam percorrer o vale do Xingu". O parecer leva a data de 29 de janeiro de 1884 . Cópia no livro de correspondência de 1881-1885 do Museu Nacional do Rio de Janeiro, comunicada graças à gentileza de D. Heloísa Alberto Tôrres, diretora do estabelecimento. - Lê-se no ofício de Ladislau Neto que o ponto mais a montante até então atingido no Xingu era a embocadura do Tucuruí, pouco acima das grandes cachoeiras, onde em 1859 se fundou uma missão. - A referência a Crévaux no texto do parecer pode dar margem a confusão, uma vez que a morte dêsse explorador não se deu naquela área.

(4) Carta de 11 de dezembro de 1884. Cópia no arquivo do Museu Nacional do Rio de Janeiro. (Informação gentilmente prestada pela diretora, D. Heloísa Alberto Tôrres).

(5) Pouco depois, o historiador F. A. Pimenta Bueno, recorrendo em especial a um mapa do ano de 1802, tentou demonstrar que o curso superior do Xingu já fora percorrido e levantado anteriormente por sertanistas brasileiros. Memória sôbre a exploração do Rio Xingu. Boletim da Sociedade Brasileira de Geografia do Rio de Janeiro, vol. I, págs. 233-258. Rio de Janeiro, 1885. 
(6) V. a obra principal de von den Steinen, Unter den Naturvollern Zentral-Brasiliens. Reiseschilderung und Ergebnisse der Zweiten SchingúExpedition 1887-1888. Dietrich Peimer. Berlim, 1894.

(7) Sôbre as fases sucessivas da etnologia brasileira, v. Egon Schaden, O estudo do indio brasileiro -... ontem e hoje. Revista de História, vol. V, págs. 385-401. São Paulo, 1952.

(8) Journal de la Société des Américanistes. Nouvelle Série; vol. XXII, págs. 221 ss. Paris, 1930.

(9) Egon Schaden, Karl von den Steinen e a etnologia brasileira. Anais do XXXI Congresso Internacional de Americanistas. São Paulo, 1955. V. também, entre outros: Gustav Roessler, Der Anteil der deutschen völkerkundlichen Erforschung des tropischen Südamerika vom Ende des 19. Jahrhunderts bis zum Beginn des Weitkrieges. Göttinger Völkerkundliche Studien, herausgegeben von Hans Plischke; págs. 268-288. In Kommission bei Otto Harrassowitz. Leipzig, 1939.

(10) Unter den Naturvölkern Zentral-Brasiliens, pág. 81.

(11) Unter den Naturvölkern Zentral-Brasiliens. Zweite Auflage als Volksausgabe. Prefácio, pág. VII. Dietrich Reimer. Berlim, 1897. De um artigo anterior, o autor reproduz ai o seguinte trecho: "Ensina-nos a observação não orientada por quaisquer preconceitos que não há absolutamente "selvagens", uma vez que em tôda parte se encontra uma ordem social e um patrimônio lingüístico e cultural dotado já dos elementos essenciais de evoluça superior; ensina-nos que é preciso ver a característica decisiva de uma cultura superior no fato de nela ir aumentando o nimero de conceitos mais gerais, a faculdade de abstração e o conhecimento das leis que regem a natureza e a vida. Não serão muitas as singularidades do pensamento dos primitivos que, substituidas ou de outra forma ateniadas, ou mesmo bem autênticas, não possam ser ainda demonstradas com tôda nitidez em nossas crenças populares, prolongando-se, através de mil raciocínios e ações obscuras, pelas classes cultas adentro, e manifestando-se acima de tudo no mundo feminino, que adora as coisas convencionais".

(12) Edição de 1892. Leipzig, K. F. Koehlers Antiquarium. 404 págs.

(13) Fato assinalado também por Wilhelm Koppers num discurso sô. bre a atividade cientifica de von den Steinen. Verhandlungen des XXIV. Internationalen Amerikanisten-Kongresses (1930), págs. XXXVI-XL. Hamburgo, 1930 .

(14) Quanto à questão da classificação lingüistica, v. os livros sôbre as duas viagens.

(15) Publicada em 1904 por Dietrich Reimer, Berlim. 128 págs.

(16) Karl von den Steinen, Sambaki-Untersuchungen in der Provinz Sta. Catharina. Verhandlungen der Berliner Gesellschaft für Anthropologie, Ethnologie und Urgeschichte. Zeitschrift für Ethnologie, vol. XIX, págs. 445-450, Berlim, 1887. 